\title{
Harmful health effects of the Deepwater Horizon Gulf oil spill exposure among people who participated in the cleanup operations
}

\author{
Mark A D’Andrea and G Kesava Reddy* \\ University Cancer and Diagnostic Centers, Houston, TX, USA
}

\begin{abstract}
Objective: Participants who worked on the 2010 Deepwater Horizon Gulf oil spill cleanup operations are at risk of compromising their health. This study assessed the adverse health effects of the Gulf oil spill exposure in subjects involved in the cleanup operations.

Methods: We reviewed medical charts and compared measures of white blood cells (WBC), platelets, hemoglobin, hematocrit, blood urea nitrogen (BUN), creatinine, alkaline phosphatase (ALP), aspartate amino transferase (AST), and alanine amino transferase (ALT) in oil spill exposed and unexposed subjects.

Results: Medical records from 478 subjects (oil spill cleanup workers, $n=239$ and unexposed, n=239) were reviewed. Oil spill cleanup workers had a significantly increased mean WBC count, hemoglobin, hematocrit, and serum creatinine compared with the unexposed subjects $(\mathrm{P}=0.000)$. In contrast, the mean platelet counts and BUN levels were significantly reduced in oil spill cleanup workers compared with the unexposed subjects $(\mathrm{P}=0.000)$. Hepatic enzymes such as ALP, AST and ALT were significantly elevated in oil spill cleanup workers compared with those of the unexposed subjects $(\mathrm{P}=0.000)$.
\end{abstract}

Conclusion: Oil spill exposure resulted in significant alterations in hematological and hepatic functions among the workers involved in oil spill cleanup operations.

\section{Introduction}

Crude oil spills are one of the most serious and tragic marine environmental disasters that can affect human health as well as cause severe pollution and damage the ecosystem $[1,2]$. Oil spills can affect human health through the effects of inherent hazardous chemical exposure and the psychological as well as socioeconomic impact on the affected communities [3,4]. As the use of fossil fuels has increased exponentially, the number of accidental oil spills into the sea has also increased posing an increase in potential human health risks. Although more than 40 oil spill disasters have occurred around the world [4], investigation on their potential human health effects has been very limited. However, it is now an emerging area of clinical investigation following the Gulf oil spill disaster in the United States.

On April 20, 2010, the explosion of the British Petroleum (BP) offshore Deepwater Horizon drilling rig in the Gulf of Mexico resulted in the second largest global oil spill in history (Figure 1). Two days later, the drilling rig burned and eventually sank into the ocean. An estimated 5,000 barrels of crude oil flowed into the Gulf of Mexico from the time the rig exploded until the well was capped on July 15, $2010[2,5]$. As a consequence, this catastrophic disaster contaminated a coastal zone spanning over 1000 miles from Texas to Florida through Louisiana, Mississippi, and Alabama [6]. During the height of the BP disaster, nearly 2 million gallons of dispersant chemicals such as Corexit was used to breakdown the oil slick. Tens of thousands of workers and volunteers were employed to aid in the clean-up activities. Additionally, a large volume of oil was gathered in to pits and later burned, generating harmful and toxic air pollutants. Consequently, the environment was polluted with hazardous components of crude oil including benzene, toluene, xylene, and ethylbenzene, as well as the particulate matter from the burning oil slick. The polluted environment with these toxic chemicals has a great threat to the physical and psychological well-being of local residents, clean-up workers, and volunteers in the affected coastal areas. This catastrophic disaster disrupted the region's fishing industry, destroyed renewable natural resources, and caused significant wildlife injury and death. This disastrous spill has raised numerous questions about its immediate and long-term potential impact on the health of those living in the oilexposed regions and surrounding communities as well as those who participated in cleanup activities of the oil spill.

It is believed that inhalation, ingestion or physical contact with these toxic chemicals can have a variety of adverse effects on human health. Potential health consequences include damage to the hematological, hepatic, renal, respiratory, neurological, and endocrine functions, as well as other systemic effects [4,7]. Previously, several studies have reported on the adverse health effects of oil spills and other man-made or natural disasters. However, these investigations were primarily focused only on the physical effects and psychological sequelae of the oil spill disasters [4,7]. It is well established that exposure to benzene and other toxic chemicals is associated with a wide range of adverse effects

*Correspondence to: $\mathrm{G}$ Kesava Reddy, PhD, MHA, University Cancer and Diagnostic Centers, 12811 Beamer Road, Houston, TX 77089, USA, Tel: (713) 474-1414; Fax: (713) 474-8477; E-mail: kreddy_usa@yahoo.com

Key words: crude oil spill, dispersants, health impact, hematological toxicity, hepatotoxicity, toxic exposure

Received: January 14, 2019; Accepted: January 22, 2019; Published: January 25, 2019 


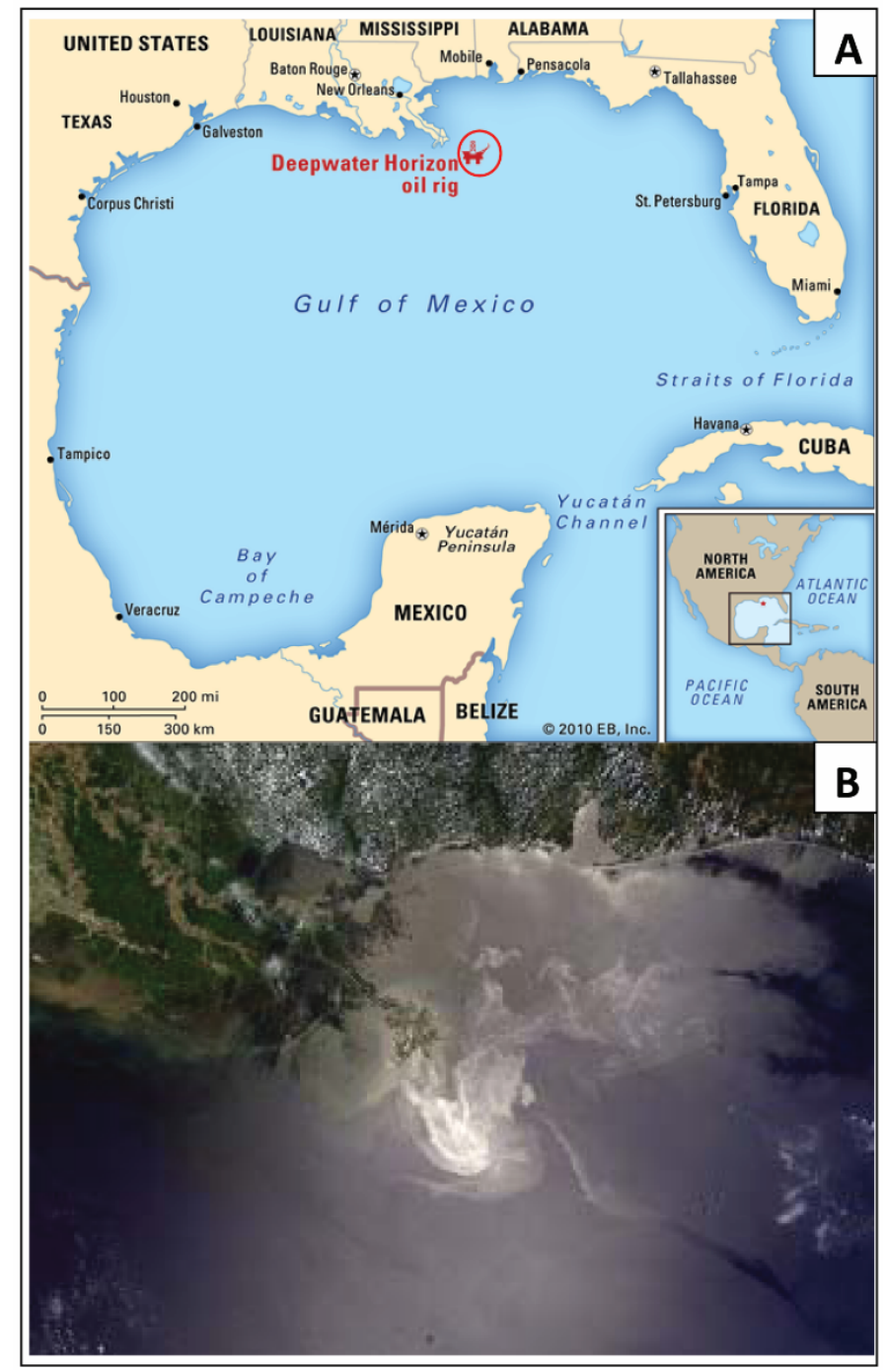

Figure 1. A. The Deepwater Horizon oil drilling rig. A. The location of the Deepwater Horizon oil rig explosion in the Gulf of Mexico, 50 miles off the Louisiana coast. B. Satellite view of The Deepwater Horizon oil spill slick by the United States National Aeronautics and Space Administration in the Gulf of Mexico.

to the central nervous, hematological, hepatic and renal systems [8-12], and increases the risk of developing carcinogenesis [13,14]. Although after an oil spill exposure, it may take years to decades to develop cancer, its immediate health effects may be seen in the hematological and hepatic parameters indicating its early toxic effects and potential for future detrimental health effects.

Our preliminary studies on the potential health effects of the oil spill exposure from the Horizon drilling rig blasting disaster revealed that human exposure to this oil spill has a potential to disrupt hematological, hepatic and other organ functions [15]. The longterm follow up analysis demonstrated that individuals involved in the oil spill cleanup operations experienced persistent alterations or worsening of their hematological, hepatic, pulmonary and cardiac functions [16]. To further substantiate the findings of these studies, we conducted a larger study to assess the adverse health effects of the Gulf oil spill exposure in workers participating in the clean-up activities. Clinical outcomes of exposed subjects were compared with a group of unexposed subjects.

\section{Materials and Methods}

\section{Subjects}

This retrospective study was approved by an Institutional Review Board. The methodology for subject selection and medical evaluation were reported previously [15]. Briefly, the subjects exposed to the oil spill were identified as participants in the oil spill clean-up activities along the coast of Louisiana. Using their medical charts, demographic and clinical data were reviewed for the subjects who underwent clinical and laboratory evaluation by an experienced physician. The study was conducted according to the principles of the Declaration of Helsinki. The personal information of the subjects was redacted to maintain their confidentiality. The unexposed subjects were living geographically at least 100 miles away from the Gulf coast where the oil spill occurred. The unexposed subjects had visited their family physicians office for a routine wellness checkup. The subjects were selected randomly by their primary care physicians for the study.

\section{Chart Review and Data Gathering}

Study investigators reviewed the clinical data of both the oil spill exposed and unexposed subjects. Laboratory data such as white blood cell (WBC) counts, platelet counts, hemoglobin, hematocrit, blood urea nitrogen (BUN), creatinine, alkaline phosphatase (ALP), aspartate amino transferase (AST), and alanine amino transferase (ALT) levels were collected and evaluated.

\section{Statistics}

Descriptive statistics were used to assess patient demographics and included means and standard deviations for each group. Variables included were WBC, platelets, hemoglobin, hematocrit, creatinine, BUN, ALP, AST, and ALT. Student's t-test was used to assess the differences between exposed and unexposed groups. The significance level was predetermined at an alpha level of 0.05 .

\section{Results}

A total of 478 subjects were included in this study. Of the 478 subjects, 239 were unexposed and 239 were involved in the clean-up activity of the Deepwater Horizon oil spill. The subjects' demographics are shown in the Table 1 . The mean age of the unexposed and oil spill exposed subjects was 49.2 and 38.9 years, respectively. Among unexposed subjects $(n=239)$, there were $36 \%(n=85)$ male and $64 \%(n$ $=154)$ female subjects. In the oil spill-exposed group $(n=239)$, there were $87 \%(n=207)$ male and $13 \%(n=32)$ female subjects.

Table 2 presents the hematologic and hepatic profiles for the unexposed versus exposed groups. Oil spill cleanup workers had a significantly increased mean WBC count $\left(\mathrm{X} 10^{3}\right.$ per $\left.\mu \mathrm{L}\right)$ compared

Table 1. Demographics and other characteristics of the subjects included in the study

\begin{tabular}{|l|l|l|}
\hline Demographics & Unexposed & Exposed \\
\hline Total subjects & $239(100 \%)$ & $239(100 \%)$ \\
\hline $\begin{array}{l}\text { Gender } \\
\text { Male }\end{array}$ & $85(36 \%)$ & $207(87 \%)$ \\
Female & $154(64 \%)$ & $32(13 \%)$ \\
\hline $\begin{array}{l}\text { Age, years } \\
\text { Mean } \\
\text { Median }\end{array}$ & 49.2 & 38.9 \\
Range & 51.5 & 40.2 \\
\hline $\begin{array}{l}\text { Age group, years } \\
<40 \text { years } \\
\quad \geq 40 \text { years }\end{array}$ & $18-90$ & $18-63$ \\
\hline
\end{tabular}


Table 2. Comparison of hematologic and hepatic indices between the unexposed and exposed subjects to oil spill

\begin{tabular}{|l|c|c|c|}
\hline Variable & $\begin{array}{c}\text { Unexposed } \\
(\mathbf{N}=\mathbf{2 3 9})\end{array}$ & $\begin{array}{c}\text { Exposed } \\
(\mathbf{N}=\mathbf{2 3 9})\end{array}$ & P Value \\
\hline WBC $(\mathrm{X} \mathrm{10}$ per dL) & $6.4 \pm 1.7$ & $7.5 \pm 2.1$ & $0.000^{*}$ \\
\hline Platelets $(\mathrm{X} \mathrm{10}$ per dL) & $278.4 \pm 67.6$ & $242.9 \pm 55.6$ & $0.000^{*}$ \\
\hline Hemoglobin $(\mathrm{g}$ per dL) & $13.8 \pm 1.3$ & $14.9 \pm 1.4$ & $0.000^{*}$ \\
\hline Hematocrit $(\%)$ & $40.4 \pm 3.5$ & $44.5 \pm 3.8$ & $0.000^{*}$ \\
\hline BUN (mg per dL) & $14.9 \pm 4.6$ & $13.2 \pm 3.4$ & $0.000^{*}$ \\
\hline Creatinine (mg per dL) & $0.9 \pm 0.2$ & $1.0 \pm 0.2$ & $0.000^{*}$ \\
\hline ALP $($ IU per L) & $55.3 \pm 13.4$ & $79.1 \pm 14.6$ & $0.000^{*}$ \\
\hline AST (IU per L) & $18.1 \pm 5.9$ & $27.7 \pm 6.5$ & $0.000^{*}$ \\
\hline ALT (IU per L) & $19.6 \pm 6.8$ & $34.3 \pm 7.9$ & $0.000^{*}$ \\
\hline
\end{tabular}

${ }^{*} \mathrm{P}=0.001$

$\mathrm{WBC}=$ White blood cells; $\mathrm{BUN}=$ Blood urea nitrogen; ALP = Alkaline phosphatase; $\mathrm{AST}$ $=$ aspartate amino transferase; $\mathrm{ALT}=$ Alanine amino transferase

with unexposed subjects $(7.5 \pm 2.1$ versus $6.4 \pm 1.7, \mathrm{P}=0.000)$. The hemoglobin $(\mathrm{g} / \mathrm{dL})$ levels were significantly increased among oil spill exposed subjects compared with the unexposed subjects $(14.9 \pm 1.4$ versus $13.8 \pm 1.3, \mathrm{P}=0.000$ ). The hematocrit levels were significantly elevated in oil spill exposed subjects compared with the unexposed subjects $(44.5 \pm 3.8$ versus $40.4 \pm 3.5, \mathrm{P}=0.000)$. The mean serum creatinine levels $(\mathrm{mg} / \mathrm{dL})$ were also significantly higher in the oil spill exposed subjects compared with the unexposed subjects $(1.0 \pm 0.2$ versus $0.9 \pm 0.2, \mathrm{P}=0.000)$. Conversely, the mean platelet count $\left(\mathrm{X} 10^{3}\right.$ per $\mu \mathrm{L}$ ) in oil spill cleanup workers was significantly reduced compared with the unexposed subjects $(242.9 \pm 55.6$ versus $278.4 \pm 67.6, \mathrm{P}=0.000)$. Similarly, the mean BUN (mg/dL) levels were significantly decreased in the oil spill exposed subjects compared with the unexposed subjects (40.4 \pm 3.5 versus $44.5 \pm 3.8, \mathrm{P}=0.000)$.

Compared with the unexposed subjects, oil spill exposed subjects had significantly elevated levels of ALP $(79.1 \pm 14.6$ versus $55.3 \pm 13.4$ $\mathrm{IU} / \mathrm{L}, \mathrm{P}=0.000$ ). The mean serum AST (IU/L) levels was significantly higher in the oil spill exposed subjects compared with the unexposed subjects $(27.7 \pm 6.5$ versus $18.1 \pm 5.9, \mathrm{P}=0.000)$. Similarly, the mean serum ALT (IU/L) levels were increased significantly in the oil exposed group compared with the unexposed group $(34.3 \pm 7.9$ versus $19.6 \pm$ $6.8, \mathrm{P}=0.000)$.

The results in Tables 3 and 4 reveal the gender differences in hematologic and hepatic indices between the unexposed subjects and those exposed to oil spill. The mean WBC count $\left(\mathrm{X} 10^{3}\right.$ per $\left.\mu \mathrm{L}\right)$ was significantly higher in both male $(7.5 \pm 2.0$ versus $6.2 \pm 1.5, \mathrm{P}=0.000)$ and female $(7.8 \pm 2.5$ versus $6.5 \pm 1.6, \mathrm{P}=0.000)$ subjects exposed to oil spill compared with the respective unexposed subjects. Similarly, the mean levels of hemoglobin and hematocrit were significantly increased in both male and female subjects exposed to oil spill compared with those unexposed male or female subjects $(\mathrm{P}=0.000)$. In contrast, the mean platelet count (X $10^{3}$ per $\left.\mu \mathrm{L}\right)$ was significantly reduced in both male $(232.3 \pm 45.2$ versus $275.1 \pm 43.4, \mathrm{P}=0.000)$ and female ( $265.6 \pm 43.8$ versus $292.7 \pm 67.4, \mathrm{P}=0.000)$ subjects exposed to oil spill compared with the respective unexposed subjects. Similarly, the mean BUN (mg per $\mathrm{dL}$ ) levels were significantly reduced in both male and female subjects exposed to oil spill compared with the respective unexposed subjects $(\mathrm{P}=0.000)$.

The mean serum ALP levels (IU/L) were significantly elevated in male $(79.5 \pm 11.5$ versus $53.0 \pm 8.7, \mathrm{P}=0.0002)$ and female $(75.1$ \pm 14.3 versus $58.2 \pm 9.5, \mathrm{P}=0.0001)$ subjects in the oil spill exposed group compared with the unexposed group. Similarly, the mean serum AST levels (IU/L) l were significantly higher in male ( $29.3 \pm 5.6$ versus
$19.9 \pm 4.9, \mathrm{P}=0.0006)$ and female $(31.8 \pm 7.4$ versus $16.6 \pm 4.8, \mathrm{P}=$ $0.0001)$ subjects in the in the oil spill exposed group compared with the unexposed group. The mean serum levels of ALT (IU/L) was also increased in male $(38.2 \pm 8.2$ versus $22.2 \pm 5.5, \mathrm{P}=0.000)$ and female $(33.9 \pm 9.2$ versus $17.3 \pm 5.3, \mathrm{P}=0.0001)$ subjects in the oil spill exposed group compared with the unexposed group (Tables 3 and 4).

To determine if the subjects' age had any impact on the health effects of oil spill exposure, we grouped subjects into $<40$ years (unexposed, $\mathrm{n}=63$ and exposed, $\mathrm{n}=137$ ) and $>40$ years (unexposed, $\mathrm{n}=176$ and exposed, $n=132$ ) age groups and compared the clinical outcomes between unexposed and oil spill exposed groups. The results in Table 5 show the differences in the hematologic and hepatic markers between the exposed and unexposed subjects among the two age groups. These findings indicate that the mean WBC count, hemoglobin, and hematocrit levels were significantly increased in both oil spill exposed age-groups compared with their matched unexposed age-groups. Conversely, the oil spill exposed group had a significantly reduced mean platelet counts compared with the unexposed group regardless of their age. Significantly reduced levels of BUN (mg per dL) were observed in older age group subjects ( $>40$ years) who were exposed to oil spill compared with their age matched unexposed group. The serum levels of hepatic enzymes (ALP, AST and ALT) were increased significantly in oil spill exposed subjects compared with those of the unexposed subjects, regardless of their age (Table 5).

\section{Discussion}

The detrimental effect of oil spill exposure on human health has become a major global public health concern around the world.

Table 3. Comparison of hematologic and hepatic indices between unexposed and oil spill exposed male subjects

\begin{tabular}{|l|c|c|c|}
\hline Variable & $\begin{array}{c}\text { Unexposed } \\
(\mathbf{N}=\mathbf{8 5})\end{array}$ & $\begin{array}{c}\text { Exposed } \\
(\mathbf{N}=\mathbf{2 0 7})\end{array}$ & P Value \\
\hline WBC $(\mathrm{X} \mathrm{10} \text { per } \mathrm{dL})^{3}$ & $6.2 \pm 1.5$ & $7.5 \pm 2.0$ & $0.000^{*}$ \\
\hline Platelets $(\mathrm{X} \mathrm{10}$ per dL) & $275.1 \pm 43.4$ & $232.3 \pm 45.2$ & $0.000^{*}$ \\
\hline Hemoglobin (g per dL) & $14.2 \pm 1.4$ & $15.3 \pm 1.3$ & $0.000^{*}$ \\
\hline Hematocrit (\%) & $42.1 \pm 4.3$ & $45.0 \pm 3.1$ & $0.000^{*}$ \\
\hline BUN (mg per dL) & $15.3 \pm 4.8$ & $13.6 \pm 3.5$ & $0.000^{*}$ \\
\hline Creatinine (mg per dL) & $1.0 \pm 0.2$ & $1.0 \pm 0.2$ & $0.325^{*}$ \\
\hline ALP (IU per L) & $53.0 \pm 8.7$ & $79.5 \pm 11.5$ & $0.000^{*}$ \\
\hline AST (IU per L) & $19.9 \pm 4.9$ & $29.3 \pm 5.6$ & $0.000^{*}$ \\
\hline ALT (IU per L) & $22.2 \pm 5.5$ & $38.2 \pm 8.2$ & $0.000^{*}$ \\
\hline
\end{tabular}

$* \mathrm{P}=0.001 ; \psi=$ did not reach statistical significance

$\mathrm{WBC}=$ White blood cells; $\mathrm{BUN}=$ Blood urea nitrogen; $\mathrm{ALP}=$ Alkaline phosphatase AST $=$ Aspartate amino transferase $;$ ALT $=$ Alanine amino transferase

Table 4. Comparison of hematologic and hepatic indices between unexposed and oil spill exposed female subjects

\begin{tabular}{|l|c|c|c|}
\hline Variable & $\begin{array}{c}\text { Unexposed } \\
(\mathbf{N}=\mathbf{1 5 4})\end{array}$ & $\begin{array}{c}\text { Exposed } \\
\mathbf{( N = 3 2 )}\end{array}$ & P Value \\
\hline WBC $\left(\mathrm{X} \mathrm{10}\right.$ p $^{3}$ per dL) & $6.5 \pm 1.6$ & $7.8 \pm 2.5$ & $0.000^{*}$ \\
\hline Platelets (X 10 per dL) $^{3}$ & $292.7 \pm 67.4$ & $265.6 \pm 43.8$ & $0.002^{*}$ \\
\hline Hemoglobin (g per dL) & $13.3 \pm 0.9$ & $14.4 \pm 1.0$ & $0.000^{*}$ \\
\hline Hematocrit (\%) & $38.6 \pm 3.2$ & $42.3 \pm 3.7$ & $0.000^{*}$ \\
\hline BUN (mg per dL) & $14.6 \pm 4.7$ & $12.3 \pm 3.8$ & $0.006^{*}$ \\
\hline Creatinine (mg per dL) & $0.8 \pm 0.1$ & $0.8 \pm 0.2$ & $0.982^{*}$ \\
\hline ALP (IU per L) & $58.2 \pm 9.5$ & $75.1 \pm 14.3$ & $0.000^{*}$ \\
\hline AST (IU per L) & $16.6 \pm 4.8$ & $31.8 \pm 7.4$ & $0.000^{*}$ \\
\hline ALT (IU per L) & $17.3 \pm 5.3$ & $33.9 \pm 9.2$ & $0.000^{*}$ \\
\hline
\end{tabular}

$* \mathrm{P}=0.001 ; \psi=$ did not reach statistical significance

$\mathrm{WBC}=$ White blood cells; $\mathrm{BUN}=$ Blood urea nitrogen; $\mathrm{ALP}=$ Alkaline phosphatase AST $=$ Aspartate amino transferase ALT $=$ Alanine amino transferase 
Table 5. Comparison of hematologic and hepatic indices by age group between unexposed and exposed subjects to the oil spill

\begin{tabular}{|c|c|c|c|c|}
\hline Variable & Age Group & Unexposed $^{\hat{\delta}}$ & Exposed $^{\beta}$ & P Value \\
\hline \multirow{2}{*}{ WBC $\left(\mathrm{X} 10^{3}\right.$ per $\left.\mathrm{dL}\right)$} & $<40$ years & $6.1 \pm 1.6$ & $7.4 \pm 2.2$ & $0.205^{\psi}$ \\
\hline & $\geq 40$ years & $6.4 \pm 1.4$ & $7.2 \pm 1.9$ & $0.000^{*}$ \\
\hline \multirow{2}{*}{ Platelets $\left(\mathrm{X} 10^{3}\right.$ per $\left.\mathrm{dL}\right)$} & $<40$ years & $286.5 \pm 53.5$ & $241.7 \pm 49.2$ & $0.000^{*}$ \\
\hline & $\geq 40$ years & $267.1 \pm 58.7$ & $238.5 \pm 52.0$ & $0.000^{*}$ \\
\hline \multirow{2}{*}{ Hemoglobin (g per dL) } & $<40$ years & $13.7 \pm 1.4$ & $15.2 \pm 1.4$ & $0.000^{*}$ \\
\hline & $\leq 40$ years & $13.8 \pm 1.2$ & $14.8 \pm 1.3$ & $0.000^{*}$ \\
\hline \multirow{2}{*}{ Hematocrit (\%) } & $\geq 40$ years & $40.9 \pm 3.6$ & $44.8 \pm 5.2$ & $0.000^{*}$ \\
\hline & $\geq 40$ years & $40.7 \pm 4.8$ & $43.6 \pm 3.5$ & $0.001 *$ \\
\hline \multirow{2}{*}{ BUN (mg per dL) } & $<40$ years & $14.1 \pm 3.9$ & $13.9 \pm 4.6$ & $0.412^{\psi}$ \\
\hline & $\geq 40$ years & $15.2 \pm 4.2$ & $13.5 \pm 3.8$ & $0.002 *$ \\
\hline \multirow{2}{*}{ Creatinine (mg per dL) } & $<40$ years & $0.8 \pm 0.2$ & $1.0 \pm 0.2$ & $0.000^{*}$ \\
\hline & $\geq 40$ years & $0.9 \pm 0.2$ & $0.9 \pm 0.2$ & $0.859^{\psi}$ \\
\hline \multirow{2}{*}{ ALP (IU per L) } & $<40$ years & $54.4 \pm 9.1$ & $77.7 \pm 13.1$ & $0.000^{*}$ \\
\hline & $\geq 40$ years & $56.3 \pm 10.7$ & $76.5 \pm 12.3$ & $0.000^{*}$ \\
\hline \multirow{2}{*}{ AST (IU per L) } & $<40$ years & $19.0 \pm 5.2$ & $31.2 \pm 8.6$ & $0.000^{*}$ \\
\hline & $\geq 40$ years & $17.8 \pm 4.6$ & $26.4 \pm 7.2$ & $0.000^{*}$ \\
\hline \multirow{2}{*}{ ALT (IU per L) } & $<40$ years & $18.3 \pm 4.8$ & $35.7 \pm 11.9$ & $0.000^{*}$ \\
\hline & $\geq 40$ years & $18.9 \pm 4.5$ & $33.5 \pm 10.1$ & $0.000^{*}$ \\
\hline
\end{tabular}

$* \mathrm{P}=0.001 ; \psi=$ did not reach statistical significance

$\mathrm{WBC}=$ White blood cells; $\mathrm{BUN}=$ Blood urea nitrogen; ALP $=$ Alkaline phosphatase; AST $=$ Aspartate amino transferase; $\mathrm{ALT}=$ Alanine amino transferase

${ }^{\delta}$ Unexposed $<40$ years: $n=63 ;{ }^{8}$ Unexposed $\geq 40$ years: $n=176$

${ }^{\beta}$ Exposed $<40$ years: $n=137 ;{ }^{\beta}$ Exposed $\geq 40$ years: $n=102$

Despite numerous accidental oil spills that have occurred around the world, only a limited number of studies have investigated their potential adverse health effects [4,7]. Most of the reported studies have focused mainly on the psychological health and physical symptoms of the affected individuals [17-23]. The goal of this study was to further characterize the changes in the hematological and hepatic functions in participants involved in the cleanup activities of the oil spill, building on our earlier study findings. This study, to the best of our knowledge, is the first and largest of its kind to assess the hematological and hepatic functions in subjects who have been exposed to the oil spill and compare them with unexposed subjects.

Historically, hematological evaluation of various indices such as WBC counts, platelet counts, hemoglobin, hematocrit BUN etc. has been widely used to diagnose many human diseases including malignant tumors. Our study findings indicate that subjects involved in the Gulf oil spill cleanup activities had significant alterations in their hematological and hepatic functions. In particular, the mean WBC counts were increased significantly in oil spill exposed subjects compared with the unexposed subjects. Similarly, the hemoglobin, and hematocrit, and serum creatinine levels were increased significantly in the oil spill exposed group compared with the unexposed group. Conversely, platelets counts were significantly decreased in oil spill exposed subjects compared with the unexposed subjects. Similarly, the BUN levels were significantly decreased in oil spill exposed subjects compared with the unexposed subjects.

The results of this study confirm our previous pilot study findings [15] in which we reported that oil spill exposed workers experienced significant alterations in their biochemical and hematological function. In addition, our findings support the previously published findings report by Khurshid and co-investigators [24] who investigated hematological and biochemical abnormalities in 100 oil spill affected subjects 4 to 6 months after the Tasman Spirit tanker disaster. Their findings indicated that there were slight increases in the levels of lymphocytes, and eosinophiles in subjects exposed to that oil spill.
It is well known that crude oil contains toxic chemicals such as benzene that adversely affects the hematopoietic system [25]. Exposure to benzene can cause bone marrow damage, which may manifest itself initially as anemia, leucopenia, and thrombocytopenia which may lead to the development of tumor. The toxic effects of benzene are thought to arise from its metabolism, which leads to numerous metabolites including benzoquinone, muconaldehydes, hydroquinone, phenol, and catechol [26]. Of these various metabolites, benzoquinone and the muconaldehydes are regarded as the most toxic chemicals with significant health effects. Thus, cleanup workers exposed to the oil spill are at high risk of developing hematopoietic disorders including malignant diseases.

Earlier studies show that oil spill exposure can affect the hepatic functions. Therefore, we assessed the liver functions by evaluating the levels of ALP, AST and ALT in the serum of the oil spill cleanup workers and compared them with those of unexposed subjects. Clinically, measurement of these hepatic enzyme levels in the serum is routinely used as markers for liver function [27]. Our findings indicate that workers who participated in the oil spill cleanup operations had significantly increased levels of ALP, AST, and ALT in their serum compared with those unexposed subjects. These results confirm the findings of our preliminary study reported earlier [15]. Moreover, our findings support the previously published findings of Jabir, et al. [28] who evaluated hepatotoxicity by measuring the changes of liver enzymes such as ALP, glutamic-pyruvic transaminase (GOT), and glutamic-oxaloacetic transaminase (GPT) in 18 petrol workers in Basrah, Iraq. Their findings similar to ours indicated that these liver enzymes were significantly elevated in petrol workers compared with the normal controls. The increased serum levels of these enzymes in those who participated in oil spill operations could be due to the overproduction or release of enzymes from their liver cells in response to stimuli of hepatocellular injury or cell death. Nonetheless, these findings suggest that these subjects exposed to the oil spill are at a higher risk of hepatic tissue toxicity compared with those of unexposed subjects.

A subgroup analysis was performed to further understand the influence of variables on the effect of oil spill exposure in subjects involved in the cleanup operations. Specifically, we compared the outcomes by gender as well as by age groups $(<40$ years, and $>40$ years) between the oil spill exposed and unexposed subjects. Our results indicated that both hematological and hepatic functions were significantly affected in the oil spill exposed group compared with the unexposed group regardless of their gender or age.

We acknowledge that there are limitations to interpreting the findings of this study. This study used a cross-sectional design and therefore, the findings of this investigation should be considered with this in mind. It is difficult to infer a causality using such a study design because the clinical outcomes were measured at one time point after the exposure to the oil spill. The outcomes observed could be influenced by compounding factors that are inherent to such a study design. Lack of baseline data on the subjects involved in the clean-up operation prior to the oil spill disaster (however, this may not be possible to be assessed for such a disaster) and absence of predefined scheme of the protocol for the study could influence or affect the interpretation of the findings. In addition, the compounding toxic effect of the oil dispersant on the current findings could not be distinguished from the toxic effect of the oil spill exposure. 
Regardless of the study limitations, our findings do reveal that oil spill exposure is associated with significant adverse health effects in those workers involved in the cleanup operations. These adverse effects from the oil spill exposure may cause impairment in the hematological and hepatic functions. Since exposure to oil constituents such as benzene, toluene and other chemicals has previously been linked with an increased risk of carcinogenesis, it is important that workers who were involved in the oil spill cleanup activity be followed consistently over time to detect further long-term toxicities of the oil spill exposure. As these carcinogenic effects have a latent period to manifest themselves, serial periodic health checkups and routine laboratory blood work as well as $\mathrm{x}$-rays and pulmonary function assessments are necessary to monitor the long-term adverse health effects of the oil spill exposure. Since the adverse health effects of oil spill exposure appear to be long-lasting, additional close follow-up studies are required to determine its long-term detrimental health impact in workers involved in the cleanup operations.

Together, the findings of this retrospective study indicate that people involved in the oil spill cleanup operations experienced alterations in their hematological and hepatic functions. Specifically, those hematological alterations included an increased WBC counts, hemoglobin, and hematocrit levels and reduced platelet counts and BUN levels in individuals exposed to the oil spill compared with unexposed subjects. Hepatic alterations seen were increased levels of ALP, AST, and ALT in the serum indicating hepatic injury in in workers involved in the cleanup operation. Additional studies are being performed to understand the other toxic health effects the oil spill exposure had among the people involved in the Gulf oil spill cleanup operations.

\section{Conflict of Interest}

None.

\section{Verification}

All authors listed in the manuscript had access to the data and a role in preparing the manuscript.

\section{Funding source}

None

\section{References}

1. Lichtveld M, Sherchan S, Gam KB, Kwok RK (2016) The deepwater horizon oil spill through the lens of human health and the ecosystem. Curr Environ Health Rep 3: 370378. [Crossref]

2. Shultz JM, Walsh L, Garfin DR, Wilson FE, Neria Y (2015) The 2010 Deepwater Horizon oil spill: the trauma signature of an ecological disaster. J Behav Health Serv Res 42: 58-76. [Crossref]

3. Laffon B, Pásaro E, Valdiglesias V (2016) Effects of exposure to oil spills on human health: Updated review. J Toxicol Environ Health B Crit Rev 19: 105-128. [Crossref]

4. D'Andrea MA, Reddy GK (2014) Crude oil spill exposure and human health risks. $J$ Occup Environ Med 56: 1029-1041. [Crossref]

5. Kwok RK, Engel LS, Miller AK, Blair A, Curry MD (2017) The GuLF STUDY: A prospective study of persons involved in the deepwater horizon oil spill response and clean-up. Environ Health Perspect 125: 570-578. [Crossref]

6. Michel J, Owens EH, Zengel S, Graham A, Nixon Z, et al. (2013) Extent and degree of shoreline oiling: Deepwater Horizon oil spill, Gulf of Mexico, USA. PLoS One 8 : e65087. [Crossref]

7. Aguilera F, Méndez J, Pásaro E, Laffon B (2010) Review on the effects of exposure to spilled oils on human health. J Appl Toxicol 30: 291-301. [Crossref]

8. D'Andrea MA, Reddy GK (2014) Health effects of benzene exposure among children following a flaring incident at the British Petroleum Refinery in Texas City. Pediatr Hematol Oncol 31: 1-10. [Crossref]
9. D'Andrea MA, Reddy GK (2014) Hematological and hepatic alterations in nonsmoking residents exposed to benzene following a flaring incident at the British petroleum plant in Texas City. Environ Health 13: 115.

10. D'Andrea MA, Reddy GK (2016) Illness symptoms experienced by children exposed to benzene after a flaring incident at the bp refinery facility in texas city. Clin Pediatr (Phila) 55: 1143-1151

11. D'Andrea MA, Reddy GK (2016) Detrimental health effects of benzene exposure in adults after a flaring disaster at the bp refinery plant in texas city. Disaster Med Public Health Prep 10: 233-239.

12. D'Andrea MA, Reddy GK (2016) Organ toxicity from benzene exposure among elderly subjects after a flaring disaster at the BP refinery plant in Texas City. $J$ Clin Gerontol and Geriatrics (in Press).

13. Yoon JH, Kwak WS, Ahn YS (2018) A brief review of relationship between occupational benzene exposure and hematopoietic cancer. Ann Occup Environ Med 30: 33 .

14. Spycher BD, Lupatsch JE, Huss A, Rischewski J, Schindera C, et al. (2017) Parental occupational exposure to benzene and the risk of childhood cancer: A census-based cohort study. Environ Int 108: 84-91

15. D'Andrea MA, Reddy GK (2013) Health Consequences among Subjects Involved in Gulf Oil Spill Clean-up Activities. Am J Med 126: 966-974.

16. D'Andrea MA, Reddy GK (2018) The development of long-term adverse health effects in oil spill cleanup workers of the Deepwater Horizon offshore drilling rig disaster. Front Public Health 6: 117.

17. Cheong HK, Ha M, Lee JS, Kwon H, Ha EH, et al. (2011) Hebei spirit oil spill exposure and subjective symptoms in residents participating in clean-up activities. Environ Health Toxicol 26: e2011007.

18. Song M, Hong YC, Cheong HK, Ha M, Kwon H, et al. (2009) [Psychological health in residents participating in clean-up works of Hebei Spirit oil spill]. J Prev Med Public Health 42: 82-88. [Crossref]

19. Lee CH, Kang YA, Chang KJ, Kim CH, Hur JI, et al. (2010) [Acute health effects of the Hebei oil spill on the residents of Taean, Korea]. J Prev Med Public Health 43: 166-173. [Crossref]

20. Na JU, Sim MS, Jo IJ, Song HG (2012) The duration of acute health problems in people involved with the cleanup operation of the Hebei Spirit oil spill. Mar Pollut Bull 64: 1246-1251. [Crossref]

21. Ha M, Kwon H, Cheong HK, Lim S, Yoo SJ, et al. (2012) Urinary metabolites before and after cleanup and subjective symptoms in volunteer participants in cleanup of the Hebei Spirit oil spill. Sci Total Environ 429: 167-173.

22. Meo SA, Al-Drees AM, Rasheed S, Meo IM, Al-Saadi MM, et al. (2009) Health complaints among subjects involved in oil cleanup operations during oil spillage from a Greek tanker "Tasman Spirit". Int J Occup Med Environ Health 22: 143-148. [Crossref]

23. Zock JP, Rodríguez-Trigo G, Pozo-Rodríguez F, Barberà JA, Bouso L, et al. (2007) Prolonged respiratory symptoms in clean-up workers of the prestige oil spill. $\mathrm{Am} \mathrm{J}$ Respir Crit Care Med 176: 610-616. [Crossref]

24. Khurshid M, Sheikh M, Iqbal S (2008) Khurshid M, Sheikh M, Iqbal S. Health of people working/living in the vicinity of an oil-polluted beach near Karachi, Pakistan. Eastern Mediterranean Health $J$ 14: 179 -182.

25. Galbraith D, Gross SA, Paustenbach D (2010) Benzene and human health: A historica review and appraisal of associations with various diseases. Crit Rev Toxicol $40 \mathrm{Suppl}$ 2: 1-46. [Crossref]

26. Kim S, Vermeulen R, Waidyanatha S, Johnson BA, Lan Q, et al. (2006). Modeling human metabolism of benzene following occupational and environmental exposures. Cancer Epidemiol Biomarkers Prev 15: 2246-2252.

27. Innerfield F (1960) Enzymes in clinical chemistry McGraw Hill Publications, New York, USA.

28. Jabir MS, Khalil OA, Taqi ZJ, Hussain HA (2016) Biochemical changes in hepatic function of petrol station attendants in Basrah. J Al-Nahrain Univ 19: 135-138.

Copyright: C2019 D'Andrea MA. This is an open-access article distributed under the terms of the Creative Commons Attribution License, which permits unrestricted use, distribution, and reproduction in any medium, provided the original author and source are credited. 